\title{
MÜHLEISEN, Hans-Otto, STAMMEN, Theo, PHILIPP, Michael, Fürstenspiegel der frühen Neuzeit
}

\section{Christophe Duhamelle}

\section{OpenEdition}

\section{Journals}

Édition électronique

URL : http://journals.openedition.org/ifha/1480

DOI : $10.4000 /$ ifha. 1480

ISSN : 2198-8943

\section{Éditeur}

IFRA - Institut franco-allemand (sciences historiques et sociales)

Référence électronique

Christophe Duhamelle, « MÜHLEISEN, Hans-Otto, STAMMEN, Theo, PHILIPP, Michael, Fürstenspiegel der frühen Neuzeit », Revue de l'IFHA [En ligne], Date de recension, mis en ligne le 01 janvier 1998, consulté le 22 septembre 2020. URL : http://journals.openedition.org/ifha/1480 ; DOI : https://doi.org/ $10.4000 /$ ifha. 1480

Ce document a été généré automatiquement le 22 septembre 2020.

(C)IFHA 


\title{
MÜHLEISEN, Hans-Otto, STAMMEN, Theo, PHILIPP, Michael, Fürstenspiegel der frühen Neuzeit
}

\author{
Christophe Duhamelle
}

1 L'Institutio Principis Christiani d'Erasme (1516) fut pour longtemps la référence absolue d'un genre à la fois littéraire et pédagogique: le »miroir des princes«. Ce type d'ouvrages, ancré dans la tradition antique, est cependant d'une grande diversité et ne cesse, jusqu'à l'aube du XIXe s., de refléter l'évolution des esprits.

2 En présentant des extraits de 18 ouvrages parus ou traduits en allemand (ainsi le Thesaurus - paru à Rome en latin en 1610 - de Chokier de Surlet, élève de Juste Lipse, est traduit à Nuremberg dès 1624) entre 1547 et 1812, ce gros recueil permet de mieux cerner un genre protéiforme, à la fois concret et épris d'idéal, pédagogique et utopique, entre leçon d'histoire et leçon d'avenir. Certains auteurs convoquent la litanie des princes bibliques, romains et germaniques pour confronter leurs mérites (comme Franz Hausmann dans son Christpolitischer Spiegel..., 1615), d'autres, comme Friedrich Carl Moser (Der Herr und der Diener, 1759) utilisent la pédagogie de la dénonciation en critiquant les cours de leur temps, dont les noms sont prudemment remplacés par des étoiles. Tous, ou presque, ont l'expérience d'une vie passée au service d'un prince ou de l'Église: ainsi de Georg Engelhard von Löhneiß, dont l'Aulico Politica paraît à l'issue d'une longue existence (1552-1622) de haut dignitaire à la cour de Wolfenbüttel.

3 Refusant de donner le "modèle« d'un genre si divers, les éditeurs de ce recueil ont cependant choisi de privilégier les extraits traitant de l'éducation et des vertus, du choix des conseillers et des principes politiques. Chaque auteur est présenté dans une notice introductive. L'utilité de l'ensemble pour toute bibliothèque un peu informée apparaît comme évidente.

Christophe DUHAMELLE 